\title{
CARBOXYMETHYL CELLULASE FROM BACILLUS SP.: ISOLATION, MACROMOLECULAR ORGANIZATION, AND CELLULAR LOCATION
}

\author{
JÖRN KRICKE, AJIT VARMA, ${ }^{1}$ DAVID MILLER, ${ }^{2}$ \\ AND FRANK MAYER* \\ Institut für Mikrobiologie der Georg-August-Universität Göttingen, \\ D-37077 Göttingen, Germany \\ ${ }^{1}$ School of Life Sciences, Jawaharlal Nehru University, New Delhi, India \\ ${ }^{2}$ Department of Molecular Sciences, James Cook University of North Queensland, \\ Townsville, Australia
}

(Received March 4, 1993; Accepted December 28, 1993)

\begin{abstract}
A Bacillus sp. strain isolated from termite (Odontotermes obesus) mount soils was found to produce extracellular carboxymethyl cellulase (CMCase). For further characterization the enzyme was isolated and purified from the culture supernatant. It revealed a molecular weight around $250 \mathrm{kDa}$ and a tetrameric structure, with a molecular weight of the subunits around $62 \mathrm{kDa}$. Only one type of subunit was found. The enzyme was active over a wide range of conditions $\left(30^{\circ} \mathrm{C}\right.$ to $65^{\circ} \mathrm{C} ; \mathrm{pH} 3.0$ to $\mathrm{pH} 11.0)$. Highest enzyme activity was measured at $50^{\circ} \mathrm{C}$ and a pH of 6.0. The enzyme was found to be not glycosylated. Glucose and cellobiose, the low molecular weight degradation products produced by the enzyme, did not induce or repress enzyme synthesis. A polyclonal antiserum was raised against the purified enzyme and applied for studies on the cellular location of the enzyme prior to secretion into the culture medium. The enzyme was shown to be located within the cytoplasm and at the cell periphery.
\end{abstract}

Cellulose functions in nature as structural material in the wall of plants; it is produced photosynthetically by fixation of carbon dioxide. Cellulose degradation is performed by bacteria, fungi, and protozoa (7). The primary process is the hydrolysis of cellulose to glucose by enzyme systems called cellulases. These are composed of endo-1,4- $\beta$-glucanase (EC 3.2.1.4., $\mathrm{C}_{1}$ cellulase) which randomly splits the 1,4- $\beta$-glucosidic linkages along the cellulose chain, exo-1,4- $\beta$-glucanase (EC 3.2.1.91., $\mathrm{C}_{\mathrm{x}}$ cellulase) which splits off the non-reducing end of the chain and

* Address reprint requests to: Dr. Frank Mayer, Institut für Mikrobiologie der GeorgAugust-Universität Göttingen, Grisebachstr. 8, D-37077 Göttingen, Germany. 
produces cellobiose, and $\beta$-glucosidase, i.e. cellobiase or $\beta$-glucohydrolase (EC 3.2.1.21.) which hydrolyzes the 1,4-linkage of cellobiose and produces glucose.

A wealth of information is available on various aspects of bacterial cellulase systems $(5,8,15,17,26)$. However, the macromolecular properties of "simple" cellulases such as those of bacilli have only scarcely been investigated.

The present communication presents details on the isolation procedure applied to obtain pure carboxymethylcellulase (CMCase) from Bacillus sp., a partial characterization of the isolated enzyme, and data on its cellular location.

\section{MATERIALS AND METHODS}

Bacterial strain and cultivation. The Bacillus sp. strain used in this investigation was collected from termite (Odontotermes obesus) mount soils located in arid and semi-arid regions in India. The cells were elongated rods about 0.8 to $1.2 \mu \mathrm{m}$ by 1.8 to $4.4 \mu \mathrm{m}$ in size; they were motile by peritrichously inserted flagella. Centrally or sub-terminally located ellipsoidal spores 0.5 to $1.0 \mu \mathrm{m}$ by 1.2 to $1.4 \mu \mathrm{m}$ in size could be observed. Thermal DNA denaturation studies indicated a $\mathrm{G}+\mathrm{C}$ content of $47.6 \%$ (data not shown). The bacteria were grown aerobically in CMC medium which contained per liter of double distilled water the following components: $\mathrm{CH}_{3} \mathrm{COONa}, 2.0 \mathrm{~g} ; \mathrm{KCl}, 1.8 \mathrm{~g} ; \mathrm{Na}_{2} \mathrm{SO}_{4}, 0.4 \mathrm{~g} ; \mathrm{CaCl}_{2}, 0.1 \mathrm{~g} ; \mathrm{MgSO}_{4} \cdot 7 \mathrm{H}_{2} \mathrm{O}, 0.2$ g; $\mathrm{FeSO}_{4} \cdot 7 \mathrm{H}_{2} \mathrm{O}, 0.01 \mathrm{~g}$; EDTA, $0.03 \mathrm{~g} ; \mathrm{K}_{2} \mathrm{HPO}_{4}, 0.3 \mathrm{~g} ; \mathrm{KH}_{2} \mathrm{PO}_{4}, 0.3 \mathrm{~g}$; yeast extract, $1.0 \mathrm{~g}$; carboxymethyl cellulose (CMC; sodium salt, low viscosity, molecular weight around 45 to $90 \mathrm{kDa}$ ), $10.0 \mathrm{~g}$ (Sigma Chemie $\mathrm{GmbH}$, Munich, Germany). The $\mathrm{pH}$ was 7.2. In control experiments, $\mathrm{CMC}$ was omitted. The bacteria were stored at $4^{\circ} \mathrm{C}$ on agar plates or agar tubes.

The cultivation of bacteria used for enzyme isolation was performed by first growing a $25 \mathrm{ml}$ culture at $30^{\circ} \mathrm{C}$ for $10 \mathrm{~h}$ which was then used as inoculum for a 300 $\mathrm{ml}$ culture again grown at $30^{\circ} \mathrm{C}$ (for $15 \mathrm{~h}$ ). Both cultures were incubated on a shaker. The $300 \mathrm{ml}$ culture was finally used as an inoculum for a $10 \mathrm{l}$ fermenter culture grown at $30^{\circ} \mathrm{C}$ for $29 \mathrm{~h}$. At this time, a considerable percentage of the CMCase was present in the culture fluid without being bound to the substrate (see below, and Discussion).

Bacteria used for electron microscopic investigation were grown in $250 \mathrm{ml}$ cultures at $30^{\circ} \mathrm{C}$. Samples were taken from various states of the cultures (beginning of the exponential growth phase, middle of the exponential growth phase, late exponential growth phase, stationary phase).

Isolation and purification of carboxymethyl cellulase (CMCase). The bacterial cells were removed from the culture fluid by centrifugation $(15,000 \times g)$. The supernatant containing CMCase and CMC-CMCase complexes was cooled and stirred in an ice bath, and cold $\left(-70^{\circ} \mathrm{C}\right) 95 \%(\mathrm{v} / \mathrm{v})$ ethanol was added slowly until an ethanol concentration of $55 \%(\mathrm{v} / \mathrm{v})$ was reached. The material precipitating by this procedure was removed by centrifugation $(22,000 \times \mathrm{g}, 10 \mathrm{~min})$; the supernatant was again treated with cold $95 \%$ ethanol until an ethanol concentration of $65 \%$ was 
reached. The pellet formed after centrifugation of this material was dissolved in 50 $\mathrm{mm}$ Tris- $\mathrm{HCl}$ buffer, $\mathrm{pH}$ 7.0. The supernatant was discarded. The solution obtained by dissolving the pellet was dialyzed overnight against $50 \mathrm{mM}$ Tris- $\mathrm{HCl}$ buffer, pH 7.0. In control experiments no effect of CMCase activity on the utilized dialyzing tubes (Visking-tubes, Serva, Heidelberg) could be observed. For determination of enzyme activity and protein concentration, aliquots of the protein solution were dialyzed against $50 \mathrm{mM} \mathrm{NaP}$ buffer (this buffer contained per liter: $\mathrm{NaH}_{2} \mathrm{PO}_{4} \cdot \mathrm{H}_{2} \mathrm{O}, 6.9 \mathrm{~g} ; \mathrm{Na}_{2} \mathrm{HPO}_{4} \cdot 2 \mathrm{H}_{2} \mathrm{O}, 8.9 \mathrm{~g} ; \mathrm{pH}$ 7.0). The material dialyzed against Tris-HCl buffer was applied onto a DEAE-Sepharose CL-6B (Pharmacia LKB Biotechnology, Uppsala, Sweden) column equilibrated with degassed buffer ( $50 \mathrm{~mm}$ Tris- $\mathrm{HCl}, \mathrm{pH} 7.0$, containing $0.02 \%, \mathrm{w} / \mathrm{v}, \mathrm{NaN}_{3}$ ). The flow rate was 1 $\mathrm{ml} / \mathrm{min}$; afterwards, the column was washed, for $4 \mathrm{~h}$, at the same flow rate with the equilibration buffer. Elution of the protein was performed with a linear $\mathrm{NaCl}$ gradient $(0.5-1.0 \mathrm{M})$ in equilibration buffer, and $10 \mathrm{ml}$ fractions were collected. The fractions containing highest CMCase activity were pooled and concentrated by ultrafiltration (YM 30 membrane, Amicon, Danvers, Massachusetts, U.S.A.). All these steps were performed at $4{ }^{\circ} \mathrm{C}$. Further enzyme purification was achieved by preparative FPLC on Superose 12 HR (Pharmacia LKB Biotechnology) equilibrated with degassed and filtered $50 \mathrm{~mm}$ Tris- $\mathrm{HCl}$ buffer $(\mathrm{pH} \mathrm{7.0)}$. Prior to application of the pooled protein fractions, the sample was centrifuged $(18,000 \times g$, $5 \mathrm{~min}$ ). Subsequently, $200 \mu \mathrm{l}$ of the resulting supernatant were applied to the FPLC column; flow rate was $0.2 \mathrm{ml} / \mathrm{min}$. The resulting fractions containing CMCase activity were pooled and concentrated by ultrafiltration. The procedure was performed at room temperature.

Protein determination and estimation of molecular weight. Protein was determined by using established procedures $(4,13,35)$. The molecular weight of the native CMCase was estimated by gradient gel electrophoresis; the method of Arcus (1) was applied. Superose 12 HR 10/30 was used for determination of the molecular weight of native CMCase by gel permeation chromatography. The elution was done with $50 \mathrm{~mm}$ Tris- $\mathrm{HCl}$ buffer, $\mathrm{pH} 7.0$, containing $0.1 \%(\mathrm{w} / \mathrm{v})$ $\mathrm{NaCl}$. Extinction of the eluate was followed at $280 \mathrm{~nm}$. Reference proteins were thyroglobulin, ferritin, catalase, aldolase, and albumin. Native PAGE of CMCase was done according to Jovin et al. (9). This approach was primarily used for CMCase activity staining in the gel. The band containing CMCase in the native PAGE was detected by activity staining according to Schwarz et al. (27).

Determination of the molecular weight of the subunits of CMCase by SDS$P A G E$. The molecular weight of the subunits of CMCase was determined by SDS polyacrylamide gel electrophoresis following established procedures $(10,28,36)$. Reference proteins were phosphorylase $b$, albumin, ovalbumin, carboanhydrase, and trypsin inhibitor. Protein staining in SDS-PAGE was done with silver nitrate according to Blum et al. (3) or according to Weber and Osborn (36) with Serva Blue instead of Coomassie Brilliant Blue. 
Determination of CMCase activity. Determination of CMCase activity was done according to Miller et al. (20).

Substrate specificity. Degradation of crystalline cellulose (Avicel PH 101, Fluka AG, Buchs, Switzerland) was checked by the method of Thayer (32).

Activity staining on agar plates. Activity staining on agar plates was performed according to Teather and Wood (31) with Congo Red.

Glycoprotein staining. Glycoprotein staining was done with the "Glycan Detection Kit" (Boehringer Mannheim, Germany). The reference glycoprotein was transferrin.

Preparation of polyclonal CMCase antiserum. Polyclonal antiserum directed against purified CMCase was produced by immunization of a rabbit with $400 \mu \mathrm{l}$ CMCase solution containing $400 \mu \mathrm{g}$ protein. Established procedures were followed (16). The IgG antibodies present in the antiserum were isolated by affinity chromatography on protein A-Sepharose CL-4B (25). Immuno reactivity of the IgG samples was tested according to Ouchterlony (23) and Oakley (22). Specificity of the immuno reaction was demonstrated by Western blotting and double immuno precipitation with peroxidase-conjugated antibodies $(24,33)$.

Electron microscopy. Negative staining of the purified CMCase was performed according to Valentine et al. (34) and Mayer and Spiess (18) with an aqueous solution of uranyl acetate $(4 \%, \mathrm{w} / \mathrm{v}, \mathrm{pH} 4.8)$. Preparation of ultrathin sections was done by application of freeze-substitution (6). Prior to preparation the bacteria were stained with Ruthenium Red (14). Localization of CMCase in the cells was achieved by the post-embedding labeling procedure $(25,29)$ using protein A-colloidal gold as marker. Appropriate controls were performed $(25,29)$. Electron micrography was done with a Philips EM 301 electron microscope at calibrated magnifications.

Fig. 1. Activity staining of Bacillus sp. on an agar plate.

The bacteria were grown on CMC medium containing $1.5 \%(\mathrm{w} / \mathrm{v})$ agar. The plates were flooded with an aqueous solution of $0.1 \%(\mathrm{w} / \mathrm{v})$ Congo Red for $30 \mathrm{~min}$ and destained with $1 \mathrm{M} \mathrm{NaCl}$ for $1 \mathrm{~h}$. Zones of clearing indicate hydrolysis of CMC.

Fig. 2. Native PAGE of CMCase after ethanol precipitation (lane a, application of $8 \mu \mathrm{g}$ protein), and of completely purified CMCase (lanes b and c, application of $5 \mu \mathrm{g}$ and $4 \mu \mathrm{g}$ protein, respectively).

Fig. 3. Detection of CMCase activity in a native polyacrylamide gel.

The supernatant of Bacillus sp. cultures grown on CMC-free media containing yeast extract (lane 1), yeast extract $+1 \%(w / v)$ glucose (lane 2$)$, and yeast extract $+1 \%(w / v)$ cellobiose (lane 3 ) was concentrated and separated by native PAGE. Lane 4 shows a partially purified CMCase sample after ethanol precipitation prepared from CMC medium. Activity appears to be not contained in a defined band but is rather distributed over a wide range, with the lower end very similar to the position of bands in lanes 1 to 3 . The gel contained the substrate CMC $(0.1 \%, w / v)$. It was incubated subsequently for $45 \mathrm{~min}$ at $45^{\circ} \mathrm{C}$ and stained with Serva Blue and Congo Red (see Materials AND Methods).

Fig. 4. SDS-PAGE of purified CMCase (lane a) and molecular size standards (lane b) showing only one type of CMCase subunit with a molecular weight of $62 \mathrm{kDa}$. 


\section{RESULTS}

Purification and characterization of carboxymethyl cellulase (CMCase)

Bacteria shown to produce and secrete CMCase (Fig. 1) were grown in a fermenter, both with and without addition of CMC. After removal of the cells from the culture medium, in both cases CMCase activity could be observed in the

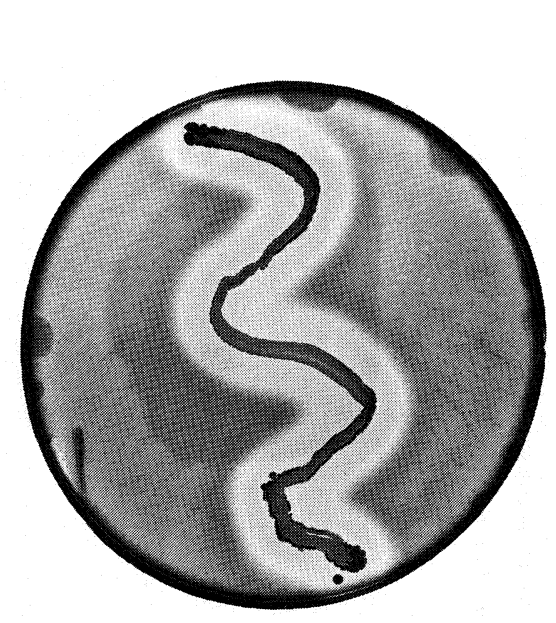

Fig. 1

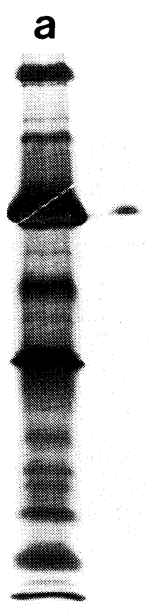

a

Fig. 2
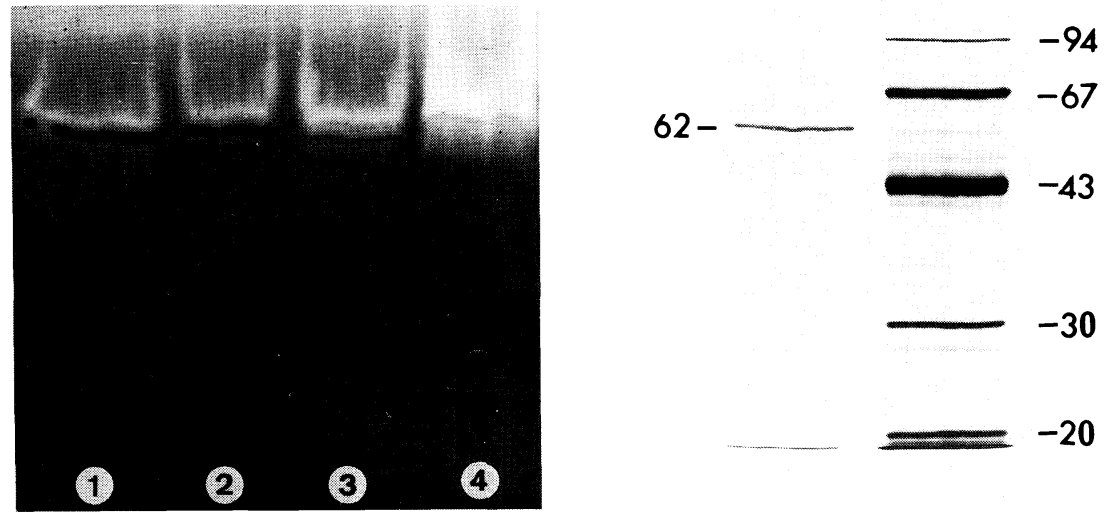

Fig. 4 
medium (data not shown). CMCase purification resulted in a homogeneous enzyme preparation (Fig. 2). Activity staining of the enzyme (Fig. 3) confirmed the identity of the purified CMCase. The molecular weight of the native enzyme was estimated to be around $250 \mathrm{kDa}$ by gel permeation chromatography or around $200 \mathrm{kDa}$ by gradient gel electrophoresis (data not shown). After SDS polyacrylamide gel electrophoresis only one band could be seen; comparison with the known molecular weight of calibration proteins revealed a value of $62 \mathrm{kDa}$ for the subunit molecular weight (Fig. 4). Based on these findings, the enzyme is assumed to be a homo-tetramer. Determination of the range of enzyme activity (data not

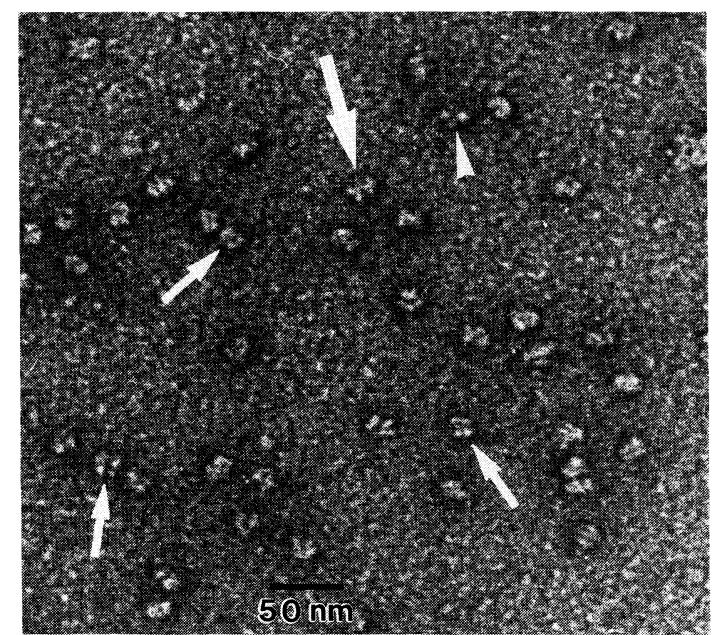

Fig. 5

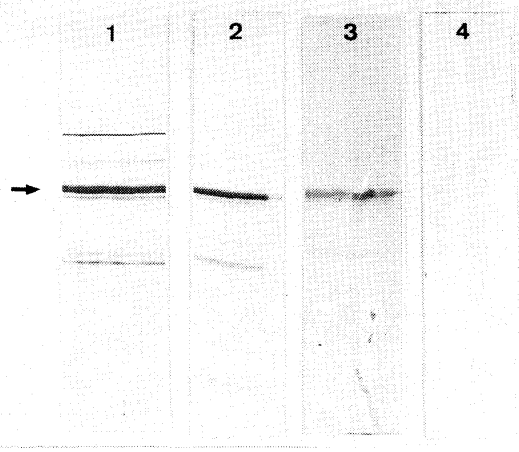

Fig. 6

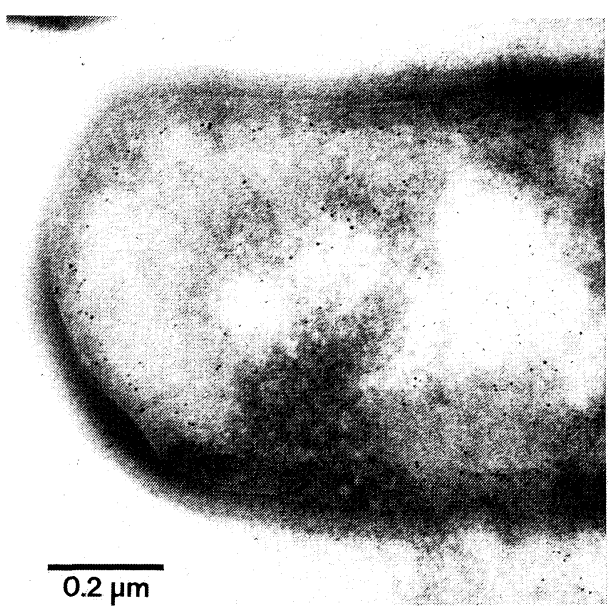

Fig. 7 
shown) resulted in the finding that the temperature range was between $30^{\circ} \mathrm{C}$ and $65^{\circ} \mathrm{C}$, with a maximum at $50^{\circ} \mathrm{C}$, and revealed a $\mathrm{pH}$ range from $\mathrm{pH} 3$ to $\mathrm{pH} 11$, with a maximum around $\mathrm{pH}$ 6. Similar experiments (data not shown) did not show any enzyme activity on crystalline cellulose (Avicel). No indication for glycosylation of the enzyme protein could be obtained (data not shown).

\section{Electron microscopy of carboxymethyl cellulase (CMCase)}

Samples containing purified CMCase, when negatively stained, exhibited various particle projections (Fig. 5). Besides broken particles, very often particles were depicted which supported the conclusion drawn from molecular weight determinations, i.e. that the enzyme is a tetramer: various types of projections were, as a common characteristic feature, made up of four intensity maxima (19).

Immuno reactivity and specificity of CMCase-specific polyclonal antisera

As shown in Fig. 6 the polyclonal antisera raised against the purified CMCase reacted specifically with the enzyme.

Cellular location of CMCase as revealed by electron microscopic immunocytochemistry

Electron microscopic immunocytochemistry with CMCase-specific antisera (Fig. 7), performed on ultrathin sections of cells synthesizing and secreting CMCase, exhibited label in the cytoplasm and close to the cell periphery, within and outside of the cell wall.

\section{DISCUSSION}

The CMC-degrading bacterial strain used for the present investigation, Bacillus sp., was isolated from termite mount soils. This material contains considerable

Fig. 5. Negatively stained preparation of purified CMCase showing particles with three (arrowhead) or four (small arrows) visible intensity maxima.

The large arrow marks a particle which could be interpreted as an example of aggregated CMCase molecules.

Fig. 6. Specificity of polyclonal CMCase antiserum demonstrated by Western blotting.

(1) SDS-PAGE of ethanol-precipitated culture supernatant. (2) Fast Greenstained protein pattern of a partially purified CMCase sample after ion-exchange chromatography and Western blotting. (3) Western blot of partially purified CMCase (see lane 2) after incubation with polyclonal CMCase antiserum and peroxidaseconjugated antibodies indicating a specific immunoreactivity of the antiserum directed against CMCase. (4) Negative control with the same fraction as in (2) and (3) after blotting and incubation with preimmunoserum and peroxidase-conjugated antibodies.

Fig. 7. Ultrathin section of Ruthenium Red-stained Bacillus sp. labeled, using the post-embedding procedure, with CMCase-specific antiserum and protein A-gold as marker.

The markers can be seen both in the cytoplasm and at the cell periphery. 
amounts of cellulosic components due to the activity of the termites. Both crystalline and amorphous cellulose may be present in such a habitat which may be assumed to be aerobic, at least in areas close to the surface. Compared to the cellulolytic enzyme system produced by the anaerobically growing bacterium Clostridium thermocellum $(2,5,11,12,21)$, the CMCase from Bacillus sp. turned out to be very "simple". It comprises only one type of subunit, it is not glycosylated, and it occurs as a tetrameric particle. The additional properties tested here (temperature and $\mathrm{pH}$ ranges) are not surprising when the origin of the bacteria is considered. As demonstrated, the Bacillus sp. CMCase did only hydrolyze amorphous cellulose (CMC); crystalline cellulose (Avicel) was not degraded. It could be tempting to speculate that "simple" cellulases may only be able to degrade amorphous cellulose, and that for degradation of crystalline cellulose very complex cellulolytic enzyme systems, combining various activities such as endoglucanases and exocellobiohydrolases as well as $\beta$-glucosidases residing in different kinds of polypeptide chains, are needed. However, very recently it was shown that a "simple" cellulase, obtained as an extracellular enzyme secreted by Streptomyces reticuli (26), acts as an Avicelase, i.e. a cellulase which is able to degrade both amorphous (soluble) and crystalline cellulose.

Electron micrographs aimed at the localization of CMCase within the cells reflect the situation at the moment of cell fixation; obviously, a considerable amount of antigenic material was on its way to the outside. However, such an approach does not provide information on the state of the CMCase (inactive, active; precursor, fully processed enzyme) (30).

Obviously, in nature the potential to degrade amorphous cellulose is sufficient to ensure supply of nutrients for certain bacteria. The aerobic Bacillus sp. is a typical example. It might be reasonable to assume that, in nature, degradation of complex cellulosic material is achieved by a combination of cellulolytic activities contributed by bacteria such as the strain investigated here, by Streptomyces strains, by fungi, and by anaerobic bacteria such as $C$. thermocellum, where the various organisms occupy aerobic regions close to the surface of the soil, or regions with low oxygen pressure or even devoid of oxygen deeper in the soil.

This work was supported by a grant provided by the Bundesministerium für Forschung und Technologie (BMFT), Germany, and by the research program "Biotechnologie" in Lower Saxony, Germany.

\section{REFERENCES}

1) Arcus, A. C., Protein analysis by electrophoretic molecular sieving in a gel of graded porosity. Anal. Biochem., 37, 53-63 (1970).

2) Bayer, E. A. and Lamed, R., Ultrastructure of the cell surface cellulosome of Clostridium thermocellum and its interaction with cellulose. J. Bacteriol., 167, 828-836 (1986).

3) Blum, H., Beier, H., and Gross, H. J., Improved silver staining of plant proteins, RNA and DNA in polyacrylamide gels. Electrophoresis, 8, 93-99 (1987). 
4) Bradford, M. M., A rapid and sensitive method for the quantitation of microgram quantities of protein utilizing the principle of protein-dye-binding. Anal. Biochem., 72, 248-254 (1976).

5) Coughlan, M. P. and Mayer, F., The cellulose-decomposing bacteria and their enzyme systems. In The Prokaryotes, Vol. I, 2nd ed., ed. by Balows, A., Trüper, H. G., Dworkin, M., Harder, W., and Schleifer, K.-H., Springer, Heidelberg/New York (1992) p. 460-516.

6) Griffiths, G., McDowall, A., Back, R., and Dubochet, J., On the preparation of cryosections for immunochemistry. J. Ultrastruct. Res., 89, 65-78 (1984).

7) Henrissat, B., Driguez, H., Viet, C., and Schülein, M., Synergism of cellulases in the degradation of cellulose. Bio/Technol., 3, 722-726 (1985).

8) Johnson, E. A., Sakajoh, M., Halliwell, G., Madia, A., and Demain, A. L., Saccharification of complex cellulosic substrates by the cellulase system from Clostridium thermocellum. Appl. Environ. Microbiol., 43, 1125-1132 (1982).

9) Jovin, T., Chrambach, A., and Naughton, N. A., An apparatus for temperature-regulated polyacrylamide gel electrophoresis. Anal. Biochem., 9, 351-369 (1964).

10) Laemmli, U. K., Cleavage of structural proteins during the assembly of the head bacteriophage $T$ 4. Nature, 227, 680-685 (1970).

11) Lamed, R., Setter, E., and Bayer, E. A., Characterization of cellulose-binding, cellulase-containing complex in Clostridium thermocellum. J. Bacteriol., 156, 828-836 (1983).

12) Lamed, R., Setter, E., Kenig, R., and Bayer, E. A., The cellulosome - a discrete cell surface organelle of Clostridium thermocellum which exhibits separate antigenic, cellulose-binding and various cellulolytic activities. Biotechnol. Bioeng. Symp., 13, 163-181 (1983).

13) Lowry, O. H., Rosebrough, N. J., Farr, A. L., and Randall, R. J., Protein measurement with folin phenol reagent. J. Biol. Chem., 193, 265-275 (1951).

14) Luft, J. H., Ruthenium red and violet: I. Chemistry, purification, methods of use for electron microscopy and mechanism of action. Anat. Res., 171, 347-368 (1971).

15) Mayer, F., Cellulolysis: Ultrastructural aspects of bacterial systems. Electron Microsc. Rev., 1, 6985 (1988).

16) Mayer, F. (ed.), Methods in Microbiology, Vol. 20: Electron Microscopy in Microbiology, Academic Press, London (1988), pp. 1-431.

17) Mayer, F., Coughlan, M. P., Mori, Y., and Ljungdahl, L. G., Macromolecular organization of the cellulolytic enzyme complex of Clostridium thermocellum as revealed by electron microscopy. Appl. Environ. Microbiol., 53, 2785-2792 (1987).

18) Mayer, F. and Spiess, E., Elektronenmikroskopische Präparationsmethoden: Negativ-Kontrastierung. Begleitveröffentlichung $C$ 1191, Institut für den Wissenschaftlichen Film, Göttingen (1976), pp. 3-9.

19) Mayer, F., Wallace, J. C., and Keech, D. B., Electron microscope studies on pyruvate carboxylase. Eur. J. Biochem., 112, 265-272 (1980).

20) Miller, G. L., Blum, R., Glennon, W. E., and Burton, A. L., Measurement of carboxymethyl cellulase activity. Anal. Biochem., 2, 127-132 (1960).

21) Nolte, A. and Mayer, F., Localization and immunological characterization of the cellulolytic enzyme system in Clostridium thermocellum. FEMS Microbiol. Lett., 61, 65-72 (1989).

22) Oakley, C. L., Antigen-antibody reactions in microbiology. Meth. Microbiol., 5, 173-218 (1971).

23) Ouchterlony, Ö., Antigen-antibody reaction in gels. Acta Pathol. Microbiol. Scand., 26, 507-515 (1949).

24) Reinhardt, M. P. and Malamud, D., Protein transfer from isoelectric focusing: The native blot. Anal. Biochem., 123, 229-235 (1982).

25) Rohde, M., Gerberding, H., Mund, T., and Kohring, G.-W., Immunoelectron microscopic localization of bacterial enzymes: Pre- and postembedding labeling techniques on resin-embedded samples. Meth. Microbiol., 20, 175-210 (1988).

26) Schlochtermeier, A., Miemeyer, F., and Schrempf, H., Biochemical and electron microscopic 
studies of the Streptomyces reticuli cellulase (Avicelase) in its mycelium-associated and extracellular forms. Appl. Environ. Microbiol., 58, 3240-3248 (1992).

27) Schwarz, W. H., Bronnenmeier, K., Gräbnitz, F., and Staudenbauer, W. L., Activity staining of cellulases in polyacrylamide gels containing mixed linkage $\beta$-glucans. Anal. Biochem., 164, 72-77 (1987).

28) Shapiro, A. L., Vinnela, E., and Maizel, J. W., Molecular weight estimation of polypeptide chains by electrophoresis in SDS-polyacrylamide gels. Biochem. Biophys. Res. Commun., 59, 815-820 (1967).

29) Slot, J. W., Geuze, H. J., and Weerkamp, A. J., Localization of macromolecular components by application of the immunogold technique on cryosectioned bacteria. Meth. Microbiol., 20, 211-236 (1988).

30) Specka, U., Spreinat, A., Antranikian, G., and Mayer, F., Immunocytochemical identification and localization of active and inactive $\alpha$-amylase and pullulanase in cells of Clostridium thermosulfurogenes EM 1. Appl. Environ. Microbiol., 57, 1062-1069 (1991).

31) Teather, R. M. and Wood, P. J., Use of congo-red polyacrylamide interactions in enumeration and characterization of cellulolytic bacteria from the bovine rumen. Appl. Environ. Microbiol., 43, 777-780 (1982).

32) Thayer, D. W., Carboxymethylcellulase produced by facultative bacteria from the hind-gut of the termite Reticulitermes hesperus. J. Gen. Microbiol., 106, 13-18 (1978).

33) Towbin, H., Staehelin, T., and Gordon, J., Electrophoretic transfer of proteins from polyacrylamide gels to nitrocellulose sheets: Procedure and some applications. Proc. Natl. Acad. Sci. USA, 76, 4350-4354 (1979).

34) Valentine, R. C., Shapiro, P. M., and Stadtman, E. R., Regulation of glutamine synthetase. XII. Electron microscopy of the enzyme from $E$. coli. Biochemistry, 7, 2143-2152 (1968).

35) Warburg, O. and Christian, W., Isolierung und Charakterisierung des Gärferments Enolase. Biochem. Z., 310, 384-421 (1942).

36) Weber, K. and Osborn, M., The reliability of molecular weight determination by dodecylsulfatepolyacrylamide gel electrophoresis. J. Biol. Chem., 244, 4406-4412 (1969). 